\title{
Pulsatile secretion of gonadotrophins, ovarian steroids and ovarian oxytocin during the luteal phase of the oestrous cycle in the cow*
}

\author{
D. L. Walters $\dagger$, D. Schams and E. Schallenberger \\ Lehstuhl für Physiologie der Fortpflanzung und Laktation, Technische Universität München, \\ 8050 Freising-Weihenstephan, Federal Republic of Germany
}

\begin{abstract}
Summary. All hormones were determined in blood samples collected simultaneously from the caudal vena cava and jugular vein at 20 -min intervals for $12 \mathrm{~h}$ during the early (Day 4 ) and mid- ( $\sim$ Day 11) luteal phases of the oestrous cycle in 7 cows. Mean concentrations of oestradiol, progesterone and oxytocin were greater $(P<0.01)$ in the vena cava than in the jugular vein. Pulses of these hormones were also more easily identifiable in the vena cava. The frequency of LH pulses was higher $(P<0.01)$ during the early luteal than during the mid-luteal phase $(8.0$ versus 3.6 pulses $/ 12 \mathrm{~h})$. During both phases, $90-96 \%$ of all LH pulses were followed within $60 \mathrm{~min}$ by a pulse of oestradiol. Basal concentration and amplitude of oestradiol pulses were greater $(P<$ $0.05)$ during the early than during the mid-luteal phase. The frequency of FSH pulses was similar to that of LH during the early luteal phase $(8.5$ and 8.0 pulses $/ 12 \mathrm{~h}$ ) but was greater $(P<0.01)$ than that of LH during the mid-luteal phase $(6.3$ versus 3.6 pulses $/ 12$ h). Thus, $41 \%$ more $(P<0.01)$ FSH pulses than LH pulses were observed during the mid-luteal phase. However, the separate FSH pulses were associated with lowamplitude short-duration pulses of $\mathrm{LH}$ as clarified by an additional study (in 3 cows) using 5-min sampling intervals: $90-100 \%$ of all $\mathrm{LH} / \mathrm{FSH}$ pulses and separate FSH pulses were secreted either concomitantly with or followed by a pulse of progesterone. However, no separate FSH pulses were associated with a pulse of oestradiol. Basal concentration and amplitude of progesterone were greater $(P<0.01)$ during the midluteal than during the early luteal phase. The frequency of oxytocin pulses was similar to that of progesterone during the mid-luteal but not during the early luteal phase. During the mid-luteal phase $97 \%$ of all oxytocin pulses were associated with a pulse of progesterone. It is concluded that (1) separate FSH pulses are secreted in addition to parallel LH and FSH pulses during the mid-luteal phase; therefore, the frequency of secretion of LH may be modulated to a greater extent by ovarian steroids than is FSH pulse frequency; (2) pulses of progesterone are probably a result of stimulation by pulses of FSH and/or LH whereas pulses of oestradiol are caused by LH pulses; (3) ovarian oxytocin and progesterone are secreted concomitantly during the mid-luteal phase of the oestrous cycle.
\end{abstract}

\section{Introduction}

The relationship between the pulsatile secretion of gonadotrophins and ovarian steroid secretion is not clearly understood. Ovarian steroids appear to regulate the frequency of LH pulses throughout

* Reprints requests to Dr E. Schallenberger.

† Present address: M.R.C. Group in Reproductive Biology, University of Western Ontario, University Hospital, London, Ontario, Canada N6A 5A5. 
the oestrous cycle of the cow (Rahe, Owens, Fleeger, Newton \& Harms, 1980; Ireland \& Roche, 1982). In the bull, each LH pulse is followed by a pulse of testosterone which indicates that the amount of testosterone secreted by the testis is determined by the frequency and amplitude of the LH pulses (Schams, Gombe, Schallenberger, Reinhardt \& Claus, 1978). In sheep with uteroovarian or ovarian autotransplants it has been demonstrated that each pulse of LH is followed by a pulse of oestradiol throughout the oestrous cycle (Baird \& McNeilly, 1981). However, there is a paucity of information available for the cow concerning the effect of pulsatile $\mathrm{LH}$ secretion on ovarian steroid response due to infrequent sampling procedures and the low concentrations of ovarian hormones during certain periods of the oestrous cycle. Concentrations of oestradiol-17 $\beta$ average $1-5 \mathrm{pg} / \mathrm{ml}$ in jugular vein plasma during the luteal phase (Wettemann, Hafs, Edgerton \& Swanson, 1972; Glencross, Munro, Senior \& Pope, 1973).

FSH is also secreted in a pulsatile manner in the cow (Schallenberger \& Peterson, 1982; Walters et al., 1982; Ireland \& Roche, 1982). However, there is no information available with regard to the interaction of pulsatile FSH and ovarian steroid secretion during the oestrous cycle.

Recently, oxytocin has been found to be present in high concentrations in the corpora lutea of sheep and cows (Wathes \& Swann, 1982). Furthermore, oxytocin appears to be secreted into the ovarian vein (Flint \& Sheldrick, 1983).

The objective of the present study was to characterize the pulsatile secretion pattern of $\mathrm{LH}$, FSH, prolactin, progesterone, oestradiol and ovarian oxytocin during the early and mid-luteal phases of the oestrous cycle and to determine possible temporal relationships between these hormones.

\section{Materials and Methods}

Experimental animals. Seven regularly cyclic cows of the local Braunvieh and Fleckvieh breeds (aged 3-5 years) were used. All cows were non-lactating and were tethered indoors throughout the duration of the experiment. They were fed hay, corn silage and energy supplement twice daily and had access to water ad libitum.

Experimental procedure. On the day before the first day of sampling, vinyl medical grade catheters (i.d. $1.0 \mathrm{~mm}$; o.d. $2 \cdot 0 \mathrm{~mm}$; Dural Plastics, Dural, N.S.W., Australia) were placed in the vena cava and in the jugular vein. Cannulae were inserted into the caudal vena cava via the tail vein using a modification of the procedure of Sears, Paape, Pearson \& Gwazdauskas (1978). An incision was made proximally to the paired haemal arches of the 5th and 6th coccygeal vertebrae while using a tranquillizer (Combelene: Bayer, Leverkusen, FRG) and intradural anaesthesia (Neocaine 2\%; WDT, Hannover, FRG). The vein was isolated and the cannula inserted and advanced maximally $75 \mathrm{~cm}$ (depending on the size of the cow) so the tip lay just cranial to the entrance of the ovarian vein. Correct placement of the catheter was confirmed when progesterone concentrations in vena cava plasma were at least 3 times higher than in jugular vein plasma.

Blood samples $(20 \mathrm{ml})$ were collected simultaneously from the vena cava and jugular vein every $20 \mathrm{~min}$ for 12 continuous hours on Day 4 (early luteal) and on Days 9,10,12 or 14 (mean \pm s.e.m. $=$ $11 \pm 1$ day, mid-luteal) of the oestrous cycle. The day of ovulation was designated as Day 1 . Blood samples were placed into heparinized tubes, cooled in an ice-water bath, centrifuged and the plasma stored at $-20^{\circ} \mathrm{C}$ until hormone analysis.

Hormone analysis. LH (Schams \& Karg, 1969a), FSH (Schams \& Schallenberger, 1976) and progesterone (Hoffmann, Kyrein \& Ender, 1973) were measured twice in duplicate and prolactin (Schams \& Karg, 1969b), oestradiol-17ß (Korenman et al., 1974; Walters \& Schallenberger, 1983) and oxytocin (Schams, 1983) were measured once in duplicate. Characteristics of the assays are summarized in Table 1. All antisera are highly specific and do not show extensive cross-reactions. 
Progesterone was extracted from 10-500 $\mu$ l blood plasma with petroleum ether and oestradiol-17 $\beta$ from 500-1000 $\mu$ l plasma with methylene chloride. Oxytocin was extracted and concentrated out of $1.0-2.0 \mathrm{ml}$ blood plasma with SEP-PAK $\mathrm{C}_{18}$ cartridges using tetrahydrofuran for the elution. The intra-assay coefficients of variation were derived from estimates for pooled plasma of 3-8 samples run at least twice in duplicates in every assay covering the whole standard curve. Samples with high hormone concentrations were measured in various dilutions to check in every assay for parallelism of unknowns and standard hormone.

Table 1. Characteristics of the hormone assays

\begin{tabular}{|c|c|c|c|c|c|c|c|c|}
\hline Hormone & Standard & Antiserum & $\begin{array}{l}\text { Final } \\
\text { dilution }\end{array}$ & $\begin{array}{c}\text { Binding* } \\
(\%)\end{array}$ & $\underset{(\%)}{\text { Recovery* }}$ & $\begin{array}{l}\text { Limit of } \\
\text { sensi- } \\
\text { tivity } \\
\text { (ng/ml) }\end{array}$ & $\begin{array}{l}\text { Intra- } \\
\text { assay } \\
\mathrm{CV} \\
(\%)^{*}\end{array}$ & $\begin{array}{l}\text { Inter- } \\
\text { assay } \\
\mathrm{CV} \\
(\%)^{*}\end{array}$ \\
\hline LH & LH-DSA† & Bovine/rabbit & $1: 500000$ & $44 \cdot 3 \pm 1 \cdot 6$ & - & $0 \cdot 25$ & $9 \cdot 1 \pm 0.5$ & $11 \cdot 2 \pm 1 \cdot 1$ \\
\hline FSH & NIH-FSH-B $1 \ddagger$ & Ovine/guinea pig & $1: 180000$ & $42 \cdot 6 \pm 2 \cdot 4$ & - & $17 \cdot 5$ & $10.9 \pm 0.5$ & $13 \cdot 2 \pm 0.9$ \\
\hline Prolactin & NIH-P-B3§ & Bovine/rabbit & $1: 160000$ & $58 \cdot 4 \pm 2 \cdot 1$ & - & 0.25 & $9 \cdot 1 \pm 1 \cdot 3$ & $14 \cdot 1 \pm 0 \cdot 9$ \\
\hline Progesterone & $\begin{array}{l}\text { Crystalline } \\
\text { progesterone }\end{array}$ & $\begin{array}{l}\text { BSA-1 } 1 \alpha \text { hydroxy- } \\
\text { progesterone- } \\
\text { hemisuccinate/ } \\
\text { rabbit }\end{array}$ & $1: 49000$ & $51 \cdot 2 \pm 1 \cdot 0$ & $84 \cdot 5 \pm 1 \cdot 4$ & 0.02 & $7 \cdot 3 \pm 0 \cdot 7$ & $11 \cdot 4 \pm 0 \cdot 6$ \\
\hline Oestradiol-17 $7 \beta$ & $\begin{array}{l}\text { Crystalline } \\
\text { oestradiol-17ß }\end{array}$ & $\begin{array}{l}\text { BSA-6-keto-17ß- } \\
\text { oestradiol- } \\
\text { 6-carboxy- } \\
\text { methyloxime/ } \\
\text { rabbit }\end{array}$ & $1: 40000$ & $43 \cdot 6 \pm 1 \cdot 5$ & $85 \cdot 8 \pm 2 \cdot 1$ & 0.0016 & $8 \cdot 5 \pm 1 \cdot 2$ & $13 \cdot 3 \pm 1 \cdot 0$ \\
\hline \multirow[t]{2}{*}{ Oxytocin } & $\begin{array}{l}\text { Synthetic } \\
\text { oxytocin }\end{array}$ & $\begin{array}{l}\text { BTG-oxytocin- } \\
\text { carbodiimide/ } \\
\text { rabbit }\end{array}$ & $1: 80000$ & $35 \cdot 6 \pm 1 \cdot 1$ & $71 \cdot 3 \pm 3 \cdot 7$ & 0.0003 & $7 \cdot 9 \pm 1 \cdot 2$ & $14 \cdot 1 \pm 1 \cdot 0$ \\
\hline & & $\begin{array}{l}\text { * Mean } \pm \text { s.e.m. } \\
\text { † Biological activ } \\
\vdots \text { Biological activ } \\
\text { § Biological activ }\end{array}$ & $\begin{array}{l}\text { vity } 1.0 \mathrm{tim} \\
\text { vity } 0.49 \mathrm{ti} \\
\text { vity } 24.1 \mathrm{i} .1\end{array}$ & $\begin{array}{l}\text { les NIH } \\
\text { mes NII }\end{array}$ & $\begin{array}{l}\text { H-S1. } \\
\text { FSH-S1. }\end{array}$ & & & \\
\hline
\end{tabular}

Statistical analysis. A pulse was defined as occurring when the value of the highest sample (peak) exceeded a preceding sample (basal) by at least 4 times the coefficient of variation of the assay for each respective hormone. There had to be at least one more value on the decreasing slope of a pulsatile hormone increase before basal concentrations were again reached. The amplitude was determined by subtracting the basal from the peak value. This was the only definition to meet the requirements of all 6 hormones studied. Temporal relationships between pulses of the various hormones were determined by calculating the number of pulses that occurred either concomitantly or within $60 \mathrm{~min}$ of the start of a pulse of another hormone. Differences in mean basal concentrations, pulse amplitudes and frequencies between the two different luteal phases were tested using Student's $t$ test, and $\chi^{2}$ analysis was used to test for differences in the number of concomitant and associated hormone pulses.

\section{Results}

LH, FSH, prolactin, progesterone, oestradiol and oxytocin were all secreted in a pulsatile manner during the early and mid-luteal phases of the oestrous cycle. However, significant changes in pulse amplitude and/or frequency occurred for all the hormones examined. 
$L H$

The frequency of LH pulses was over 2 -fold greater $(P<0.01)$ during the early than in the midluteal phase (Text-fig. 1, Table 2). However, the mean concentration and pulse amplitude did not differ $(P>0.05)$ (Table 2). There was no significant difference in basal concentration, pulse frequency or pulse amplitude of LH in jugular vein and vena cava plasma (data not given).

\section{Oestradiol-17 $\beta$}

Mean concentrations of oestradiol-17 $\beta$ were lower in the jugular vein than in the vena cava during the early $(P<0.05)$ and the mid- $(P<0.01)$ luteal phase (Table 2$)$. It was not possible to detect pulses of oestradiol in jugular vein plasma due to the low concentrations but pulses were readily detected in vena cava plasma (Text-fig. 1 ). Only data from vena cava plasma concentrations were utilized to examine the pattern of oestradiol secretion. Pulse frequency was greater $(P<$ $0.001)$ during the early luteal phase than during the mid-luteal phase (Table 2). Mean concentration and amplitude of the oestradiol pulses were also greater $(P<0.01)$ during the early luteal phase but there was considerable variation between animals during this phase (Text-fig. 2). The pulsatile secretion pattern of oestradiol was similar to that of LH during both luteal phases (Text-fig. 1).
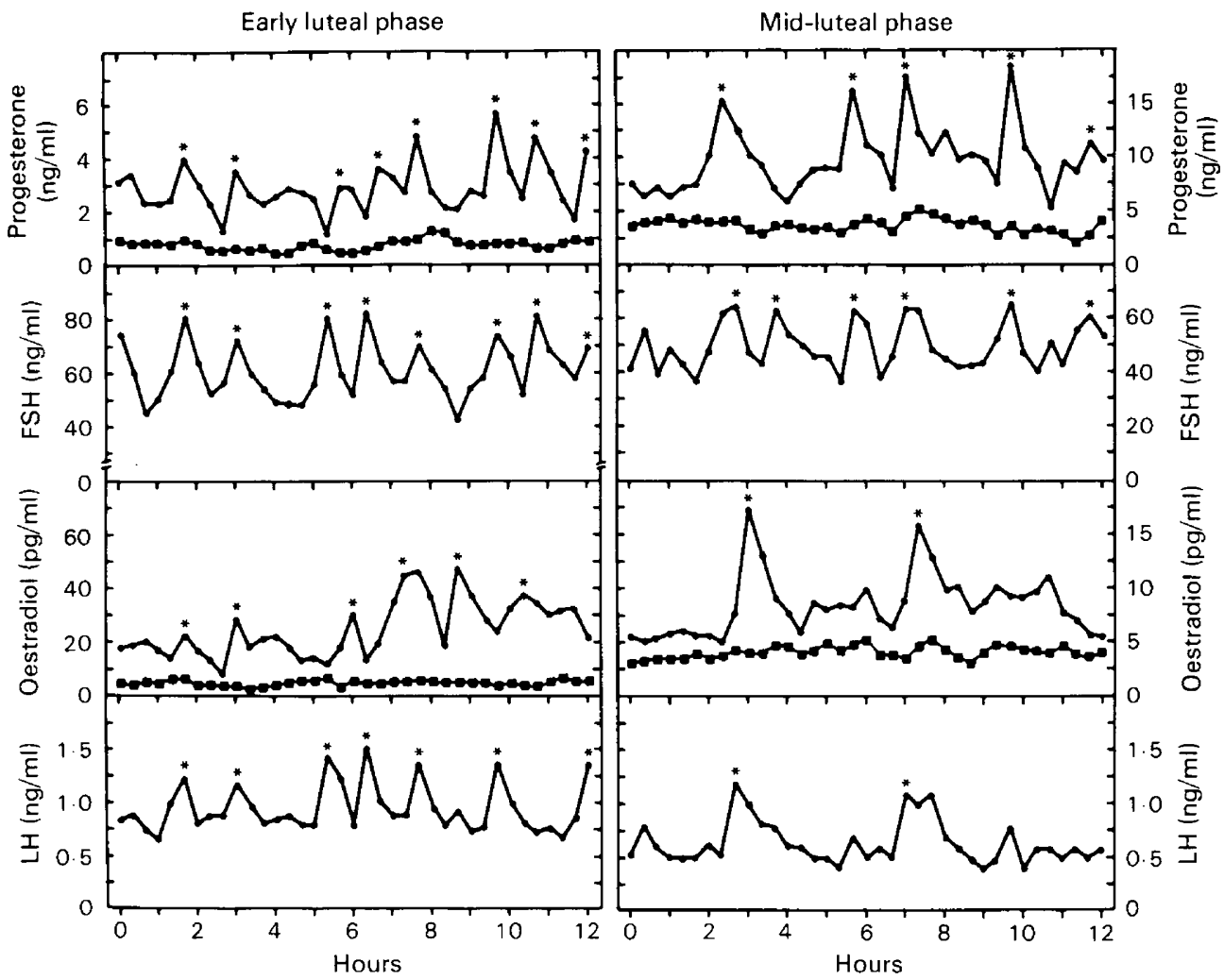

Text-fig. 1. Hormone profiles from vena cava ( () ) and jugular vein $(\square)$ blood samples collected at 20-min intervals for $12 \mathrm{~h}$ during the early and mid-luteal phases of the oestrous cycle in one representative cow (Cow I). Pulses are indicated by asterisks. Note that the scale is 2.5 times lower for progesterone and 4 times higher for oestradiol during the early luteal than the midluteal phase. 
Table 2. Secretory pattern (mean \pm s.e.m.) of LH, FSH, oestradiol-17ß, progesterone and oxytocin in vena cava and jugular vein plasma during the early and mid-luteal phases of the oestrous cycle in 7 cows

\begin{tabular}{|c|c|c|c|c|}
\hline & \multicolumn{2}{|c|}{ Early luteal phase } & \multicolumn{2}{|c|}{ Mid-luteal phase } \\
\hline & Vena cava & Jugular vein & Vena cava & Jugular vein \\
\hline \multicolumn{5}{|c|}{ Overall mean concentration } \\
\hline $\mathrm{LH}(\mathrm{ng} / \mathrm{ml})$ & & $1 \cdot 1 \pm 0.05$ & & $1.0 \pm 0.08$ \\
\hline FSH $(\mathrm{ng} / \mathrm{ml})$ & & $53 \cdot 4 \pm 4 \cdot 1$ & & $47 \cdot 5 \pm 2 \cdot 7$ \\
\hline Oestradiol (pg/ml) & $23.6 \pm 9 \cdot 7 \dagger$ & $5 \cdot 6 \pm 0.7$ & $7 \cdot 7 \pm 0 \cdot 3 \ddagger$ & $4 \cdot 0 \pm 0 \cdot 2$ \\
\hline Progesterone $(\mathrm{ng} / \mathrm{ml})$ & $3.8 \pm 0.4^{*} \ddagger$ & $0.8 \pm 0.1$ & $12 \cdot 3+2 \cdot 0 t$ & $4.0 \pm 0.6$ \\
\hline Oxytocin $(\mathrm{pg} / \mathrm{ml})$ & $4.0 \pm 0.9 \dagger$ & $2 \cdot 2 \pm 0.4$ & $5 \cdot 6 \pm 0.9$ & $2.7 \pm 0.5$ \\
\hline \multicolumn{5}{|l|}{ Pulses/12h } \\
\hline LH & & $8 \cdot 0 \pm 0 \cdot 4^{*}$ & & $3 \cdot 6 \pm 0.4$ \\
\hline FSH & & $8 \cdot 5 \pm 0 \cdot 3^{*}$ & & $6.3 \pm 0.5$ \\
\hline Oestradiol & $7 \cdot 2 \pm 0 \cdot 2^{*}$ & & $3 \cdot 6 \pm 0.5$ & \\
\hline Progesterone & $8 \cdot 3 \pm 0.3^{*}$ & & $6.0 \pm 0.6$ & \\
\hline Oxytocin & $2 \cdot 0 \pm 0 \cdot 4^{*}$ & & $4.7 \pm 0.6$ & \\
\hline \multicolumn{5}{|l|}{ Pulse amplitude } \\
\hline $\mathrm{LH}(\mathrm{ng} / \mathrm{ml})$ & & $0 \cdot 6 \pm 0 \cdot 1$ & & $0.7 \pm 0.05$ \\
\hline FSH $(\mathrm{ng} / \mathrm{ml})$ & & $18 \cdot 5 \pm 1.6$ & & $16 \cdot 6 \pm 1 \cdot 7$ \\
\hline Oestradiol $(\mathrm{pg} / \mathrm{ml})$ & $16 \cdot 8 \pm 6 \cdot 8^{*}$ & & $6 \cdot 4 \pm 1 \cdot 7$ & \\
\hline Progesterone (ng/ml) & $2 \cdot 7 \pm 0 \cdot 3^{*}$ & & $8.8 \pm 1.2$ & \\
\hline Oxytocin $(\mathrm{pg} / \mathrm{ml})$ & $3 \cdot 3 \pm 3 \cdot 0$ & & $3 \cdot 3 \pm 0.5$ & \\
\hline
\end{tabular}

* $P<0.01$ compared with corresponding mid-luteal phase value.

$+P<0.05$ compared with corresponding jugular vein value.

$\$ P<0.01$ compared with corresponding jugular vein value.

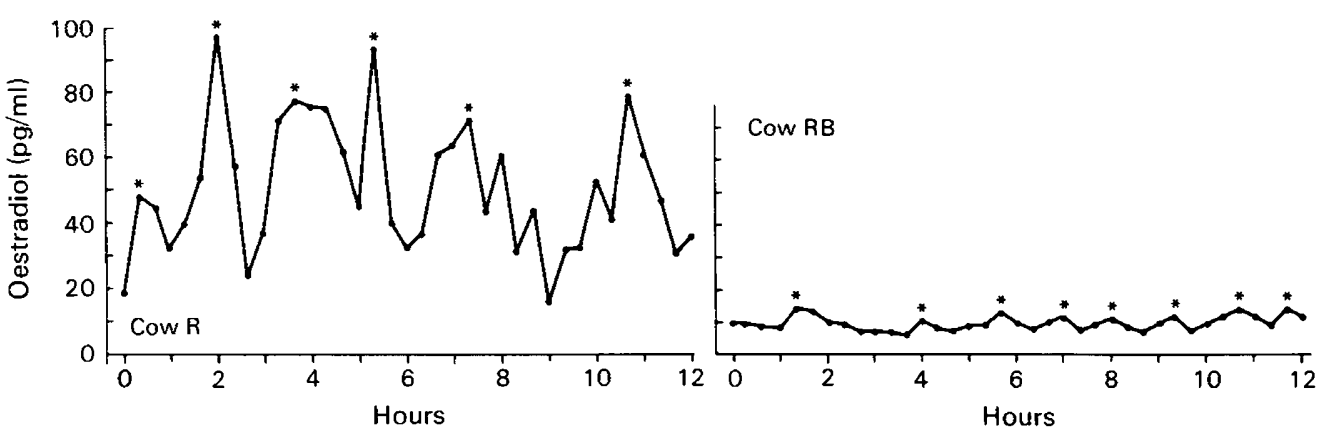

Text-fig. 2. Oestradiol profiles from vena cava blood samples collected at 20-min intervals for $12 \mathrm{~h}$ during the early luteal phase of the oestrous cycle in 2 cows. Pulses are indicated by asterisks. The low concentrations of Cow RB were not due to improper catheter position (see also Text-figs 3 \& 4).

\section{FSH}

Basal concentration and pulse amplitude were similar $(P>0.05)$ during both luteal phases. However, there was a decrease $(P<0.01)$ in pulse frequency during the mid-luteal phase compared to the early luteal phase (Table 2). The frequency of pulsatile FSH release was similar to that of LH during the early luteal phase but was more $(P<0.01)$ frequent during the mid-luteal phase (Textfig. 1; Table 2). The mean concentration of FSH was similar $(P>0.05)$ in jugular vein and vena cava plasma (data not given). 


\section{Progesterone}

Mean progesterone concentrations in jugular vein plasma were lower $(P<0.01)$ during both luteal phases than in vena cava plasma (Table 2 ). It was not possible to detect any progesterone pulses in jugular vein plasma during the early luteal phase and significantly fewer $(P<0.01)$ pulses were observed in jugular vein plasma than in vena cava plasma during the mid-luteal phase (Textfig. 1). Since progesterone pulses were readily detected in vena cava plasma during both luteal phases only data from vena cava plasma were further evaluated. Pulse amplitude and basal concentration were greater $(P<0.01)$ during the mid-luteal than during the early luteal phase (Table 2), but frequency of pulses was lower $(P<0.01)$ during the mid-luteal phase. The pulsatile secretion pattern was similar to that of FSH during both luteal phases (Text-fig. 1; Table 2).

\section{Oxytocin}

As found for the steroids, the mean concentration of oxytocin was higher $(P<0.05)$ in vena cava than in jugular vein plasma (Table 2; Text-fig. 3). Vena cava data were therefore used to analyse the patterns of ovarian oxytocin secretion. Basal concentration and pulse amplitude were not different $(P>0.05)$ between the two luteal phases (Table 2). However, pulse frequency was higher $(P<0.01)$ during the mid-luteal than during the early luteal phase (Table 2$)$. The pulsatile secretion patterns of oxytocin and progesterone were comparable during the mid-luteal (Text-fig. 4) but not during the early luteal phase.

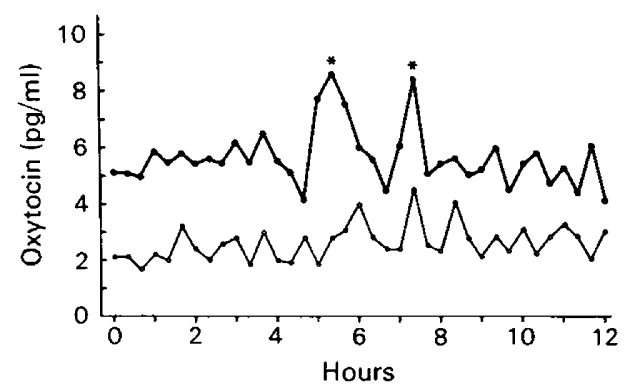

Text-fig. 3. Oxytocin profiles from vena cava (O) and jugular vein $(O)$ blood samples collected at 20-min intervals for $12 \mathrm{~h}$ during the early luteal phase of the oestrous cycle in one representative cow (Cow RB). Pulses are indicated by asterisks.

\section{Prolactin}

Basal concentrations, pulse amplitude and pulse frequency of prolactin varied considerably. Distinct pulses were observed in some cows (Text-fig. 5) but not in others depending especially on the season in which the experiment was carried out. In some cows a few pulses were associated with pulses of LH and FSH but there was no consistent temporal association to pulses of any other hormone. There was no difference between the two luteal phases.

\section{Relationship between $\mathrm{LH}$ and FSH pulses}

During the early and mid-luteal phases of the cycle $96-100 \%$ of all $\mathrm{LH}$ pulses were associated with a pulse of FSH (Table 3). Also, 91\% of all FSH pulses were associated with a pulse of LH during the early luteal phase. However, only $59 \%$ of all FSH pulses were associated with a pulse of LH during the mid-luteal phase (Table 3). Thus, $41 \%$ more $(P<0.01)$ FSH pulses than LH pulses were observed during the mid-luteal phase (Table 3 ). 


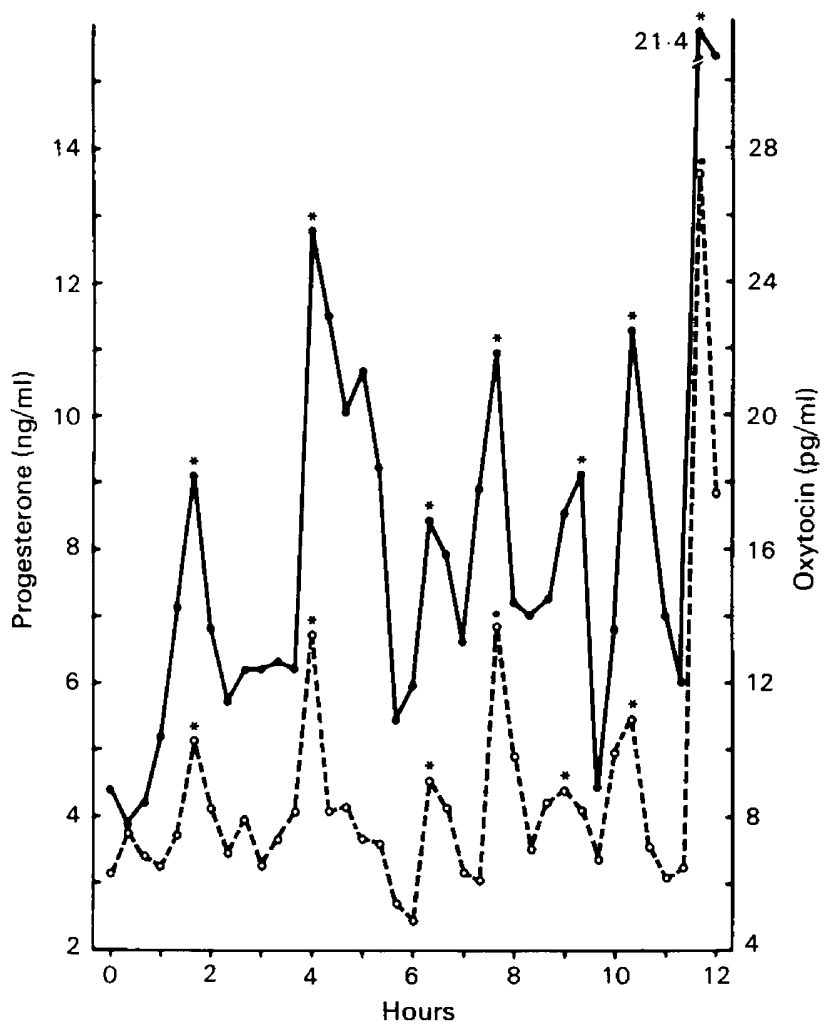

Text-fig. 4. Oxytocin (O-- $\mathrm{O})$ and progesterone (O-O) profiles from vena cava blood samples collected at 20 -min intervals for $12 \mathrm{~h}$ during the mid-luteal phase of the oestrous cycle in one representative cow (Cow RB). Pulses are indicated by asterisks.

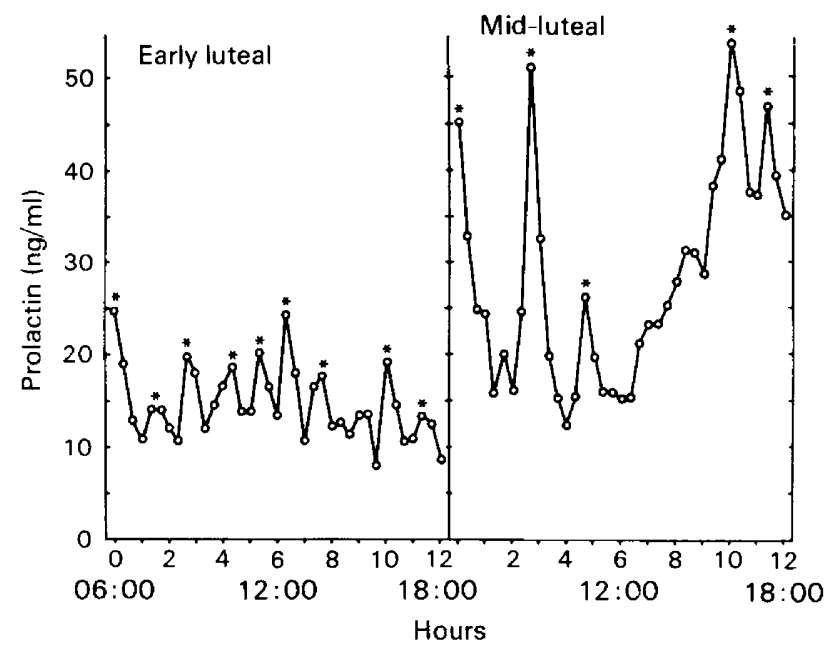

Text-fig. 5. Prolactin profiles from jugular vein blood samples collected at 20 -min intervals for $12 \mathrm{~h}$ during the early and mid-luteal phases of the oestrous cycle in Cow R. Pulses are indicated by asterisks. 
Table 3. Association of LH pulses with FSH pulses and oxytocin pulses with progesterone pulses during the early and mid-luteal phases of the oestrous cycle in 7 cows

\begin{tabular}{lcclll}
\hline & \multicolumn{4}{c}{ Concomitant pulses } \\
\cline { 2 - 3 } & \multicolumn{2}{c}{ Early luteal phase } & & \multicolumn{2}{c}{ Mid-luteal phase } \\
\cline { 2 - 3 } \cline { 5 - 6 } Pulses compared & Total & $\%$ & & Total & $\%$ \\
\hline LH:FSH & $32 / 32$ & 100 & $26 / 25$ & 96 \\
FSH:LH & $35 / 32$ & $91^{*}$ & $44 / 26$ & 59 \\
Oxytocin:progesterone & $9 / 9$ & 100 & $33 / 32$ & 97 \\
Progesterone:oxytocin & $31 / 9$ & $29^{*}$ & $37 / 32$ & 86 \\
\hline
\end{tabular}

$* P<0.01$ compared with mid-luteal value.

It was apparent that the separate pulses of FSH observed in some cows during the mid-luteal phase may have been associated with LH increases of very low amplitude and of short duration which did not qualify as a regular pulse by our criteria (Text-fig. 1). To clarify this further, the jugular vein of 3 cows was cannulated on Day 11 of the oestrous cycle. On Day 12, blood samples were collected every 5 min over $12 \mathrm{~h}$. The samples were then assayed for LH and FSH (the intraassay CV was 6.6 and $10.6 \%$, respectively). The secretion pattern from 2 cows is shown in Text-fig. 6 . The results supported the earlier belief that the separate FSH pulses observed during the midluteal phase are generally associated with low-amplitude LH pulses lasting for about 2 consecutive 5 -min samplings.

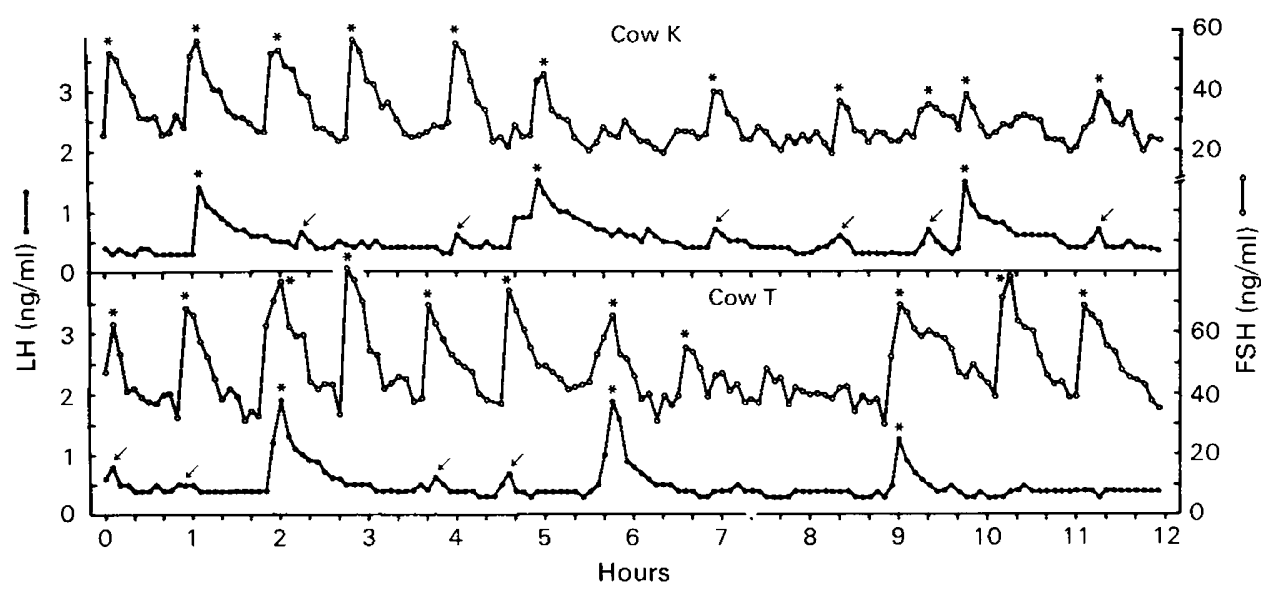

Text-fig. 6. LH (O) and FSH $(O)$ profiles from jugular vein blood samples collected at 5-min intervals for $12 \mathrm{~h}$ during the mid-luteal phase of the oestrous cycle in 2 cows. Pulses are indicated by asterisks and low-amplitude, short-duration pulses of $\mathrm{LH}$ are indicated by arrows.

\section{Relationship between gonadotrophin and steroid pulses (based on 20-min sampling intervals)}

Pulses of LH were released concomitantly with pulses of FSH and are thereby designated as LH/FSH pulses in this section. A close temporal relationship appeared to exist between pulses of LH/FSH and pulses of oestradiol (Text-fig. 1). During both luteal phases, $90-96 \%$ of all LH/FSH pulses were followed within $60 \mathrm{~min}$ by a pulse of oestradiol (Table 4 ). The mean time between the start of an LH/FSH pulse and an oestradiol pulse was similar during both luteal phases and varied between 23 and $25 \mathrm{~min}$ (Table 4). No separate FSH pulses were associated with a pulse of oestradiol 
(Text-fig. 1), whereas $93-100 \%$ of all LH/FSH pulses and separate FSH pulses were secreted either concomitantly with or followed by a pulse of progesterone (Text-fig. 1; Table 4). During the early and mid-luteal phases, progesterone pulses followed LH/FSH pulses and separate FSH pulses by a mean time that varied between 5 and $9 \mathrm{~min}$.

Table 4. Association of gonadotrophin pulses with steroid pulses (concomitant or within $60 \mathrm{~min}$ of the start of a gonadotrophin pulse) during the early and mid-luteal phases of the oestrous cycle in 7 cows

\begin{tabular}{|c|c|c|c|c|c|c|}
\hline \multirow[b]{3}{*}{ Pulses compared } & \multicolumn{6}{|c|}{ Associated pulses } \\
\hline & \multicolumn{3}{|c|}{ Early luteal phase } & \multicolumn{3}{|c|}{ Mid-luteal phase } \\
\hline & Total & $\%$ & $\underset{(\min ) \dagger}{\text { Time lag }}$ & Total & $\%$ & $\underset{(\min ) \dagger}{\text { Time lag }}$ \\
\hline LH/FSH : oestradiol & $31 / 28$ & 90 & $22 \cdot 9 \pm 3 \cdot 2^{*}$ & $25 / 24$ & 96 & $24 \cdot 4 \pm 3 \cdot 2^{*}$ \\
\hline LH/FSH : progesterone & $31 / 29$ & 93 & $9 \cdot 1 \pm 2 \cdot 5$ & $25 / 24$ & 96 & $8 \cdot 0 \pm 2 \cdot 4$ \\
\hline FSH : progesterone & $3 / 3$ & 100 & $6.7 \pm 6 \cdot 6$ & $18 / 17$ & 94 & $5 \cdot 0 \pm 2 \cdot 2$ \\
\hline
\end{tabular}

* $P<0.001$ compared with the 2 values below.

$\dagger$ Mean ( \pm s.e.m.) time between gonadotrophin pulses and steroid pulses.

The time between the start of a gonadotrophin pulse and an oestradiol pulse was longer $(P<$ $0 \cdot 001)$ than the time between a gonadotrophin pulse and a progesterone pulse during both luteal phases of the cycle (Table 4).

\section{Relationship between progesterone and oxytocin pulses}

During both luteal phases, $97-100 \%$ of all oxytocin pulses were associated with pulses of progesterone (Text-fig. 4; Table 3). However, only 29 and $86 \%$ of all progesterone pulses were associated with oxytocin pulses during the early and mid-luteal phases, respectively (Table 3 ).

\section{Discussion}

Pulses of $\mathrm{LH}$ were always secreted concomitantly with pulses of FSH suggesting that gonadotrophin-releasing hormone $(\mathrm{GnRH})$ is the sole hypothalamic releasing hormone for both LH and FSH (Convey, 1973). The present results confirm studies of Rahe et al. (1980), Schallenberger, Schams, Bullermann \& Walters (1984) and Walters \& Schallenberger (1984) who reported considerable changes in LH pulse frequency during the oestrous cycle in the cow.

A marked relationship between pulsatile LH secretion and oestradiol secretion was observed during both luteal phases as almost all pulses of $\mathrm{LH}$ were followed by a distinct pulse of oestradiol. However, there was more frequent progesterone than LH secretion during the mid-luteal phase, confirming the results of Hixon, Pijanowski, Weston, Shanks \& Wagner (1983). Even though all LH pulses were secreted concomitantly with FSH pulses it was assumed that a relationship existed primarily between $\mathrm{LH}$ and oestradiol. This assumption was based on the observation that no separate FSH pulses were associated with a pulse of oestradiol. In sheep (Baird \& McNeilly, 1981) each pulse of $\mathrm{LH}$ is followed by a pulse of oestradiol. The cow therefore appears to be similar to the ewe (McNeilly, O'Connell \& Baird, 1982) in that the amount of oestradiol secretion is determined by the frequency of the LH pulses. The high number of LH pulses observed during the early luteal phase may not only increase oestradiol secretion by increasing the number of oestradiol pulses but may also increase the responsiveness of the follicle to the LH pulses, since an increase in the amplitude of the oestradiol pulses was also observed during the early luteal phase. In some cows, the 
concentrations of oestradiol during the early luteal phase were comparable to concentrations observed just before the preovulatory LH surge (Glencross et al., 1973; Walters \& Schallenberger, 1984). However, it is probable that a preovulatory LH surge was blocked at this time by the low progesterone concentrations (Short, Randel, Staigmiller \& Bellows, 1979).

Oestradiol can also inhibit pulsatile LH secretion in cows (Walters et al., 1982). However, it is known that a combination of oestradiol and progesterone is the most effective in inhibiting tonic LH secretion (Beck, Smith, Seguin \& Convey, 1976). With this in mind, it is proposed that during the mid-luteal phase (when progesterone concentrations are high) each pulse of oestradiol negatively feeds back on the pituitary and/or hypothalamus to inhibit the subsequent release of a pulse of $\mathrm{LH}$ for a period lasting over several hours. This would then explain why more pulses of FSH than LH were observed during the mid-luteal phase since it is known that low concentrations of oestradiol do not inhibit either basal or pulsatile secretion of FSH in the cow (Padmanabhan \& Convey, 1981; Roche \& Ireland, 1981; Ireland \& Roche, 1982; Walters et al., 1982). Also, oestradiol in combination with progesterone is no more effective than progesterone alone in suppressing FSH secretion (Goodman, Pickover \& Karsch, 1981). The observations (from the 5min sampling study) that the separate FSH pulses were associated with low-amplitude pulses of LH support this proposal.

A striking relationship between pulsatile FSH secretion and progesterone secretion was observed during both luteal phases as almost all pulses of FSH were followed by or were concomitant with a pulse of progesterone. Since $97 \%$ of the separate FSH pulses were associated with progesterone pulses, it is possible that, at least in the cow, FSH may be the principal hormone that stimulates progesterone secretion. This does not exclude a luteotrophic action of LH (Hoffmann et al., 1974) in addition to a stimulatory action of FSH on progesterone release in the cow. A temporal relationship between FSH and progesterone pulses has also been observed in pregnant cows by Schallenberger, Rampp \& Walters (1983) at a time when pulsatile LH secretion was completely abolished. Foster, Lamming \& Peters (1980) found an association between pulses of FSH, LH and progesterone in the cow but they concluded that stimulation of progesterone secretion was only due to the $\mathbf{L H}$ pulses and not the FSH pulses. Numerous in-vitro studies have shown that FSH is capable of stimulating progesterone secretion from rat and pig granulosa cells (Thanki \& Channing, 1978; Dorrington \& Armstrong, 1979; Adashi, Jones \& Hsueh, 1981). In an early in-vitro study, Romanoff (1966) perfused bovine luteal ovaries with FSH and observed an increase in progesterone secretion. There are also specific receptors for FSH in the corpus luteum of the cow (Mann \& Niswender, 1983).

Even though FSH pulse frequency during the mid-luteal phase was greater than that of LH, it was less than the FSH and LH pulse frequency during the early luteal phase. Since Padmanabhan \& Convey (1981) reported that progesterone does not inhibit FSH secretion from the pituitary, the slight reduction in FSH pulse frequency during the mid-luteal phase could be a result of negative feedback inhibition by progesterone on GnRH secretion (Goodman \& Karsch, 1980). Also, in the absence of luteal phase concentrations of progesterone, the interpulse interval for FSH is 40-80 min in cows (Schallenberger \& Peterson, 1982; Walters \& Schallenberger, 1984; Schallenberger et al., 1984) and the interpulse interval for GnRH is approximately $40 \mathrm{~min}$ in ovariectomized ewes (Levine, Pau, Ramirez \& Jackson, 1982). This proposal for regulation of pulsatile FSH secretion does not necessarily account for changes in basal FSH concentrations. It has been shown that basal FSH concentrations decrease during the follicular phase of the oestrous cycle in cows (Walters \& Schallenberger, 1984) and ewes (Baird \& McNeilly, 1981; Goodman et al., 1981) at a time when FSH pulse frequency is actually at its highest (Waiters \& Schallenberger, 1984). Several studies have reported failure to inhibit basal secretion of FSH in ovariectomized cows (Kesner, Padmanabhan \& Convey, 1982) or ewes (Goodman et al., 1981) to levels observed in intact control animals with implants or constant infusions of progesterone and oestradiol. It therefore seems possible that another hormone, such as inhibin, may be involved in regulating changes in basal FSH secretion (and possibly $\mathbf{L H}$ ) in the cow. A negative relationship between progesterone and 
inhibin production by bovine granulosa cells has been reported (Henderson \& Franchimont, 1981) and this might explain the decrease in basal FSH concentrations during the follicular phase of the cow, although Kesner \& Convey (1982) found that concentrations of exogenous oestradiol, similar to the ones found during the periovulatory phase, can suppress basal FSH concentrations.

A relationship between pulses of progesterone and pulses of oxytocin was observed in the present study. Other studies with sheep have shown that basal progesterone concentrations and oxytocin concentrations changed concomitantly during the oestrous cycle (Sheldrick \& Flint, 1981; Webb, Mitchell, Falconer \& Robinson, 1981; Schams, Lahlou-Kassi \& Glatzel, 1982). Almost all oxytocin pulses were associated with a progesterone pulse, suggesting a common mechanism of release. However, more pulses of progesterone were consistently secreted, especially during the early luteal phase, than were pulses of oxytocin. Therefore, a common mechanism of release for both oxytocin and progesterone may not necessarily exist. It is possible that prostaglandin (PG) F$2 \alpha$ is responsible for the pulsatile secretion of ovarian oxytocin since exogenous prostaglandin causes the release of oxytocin from the ovary (Flint \& Sheldrick, 1983; Schallenberger et al., 1984). Also 13,14-dihydro-15-keto-PGF-2 $\alpha$ (PGFM) episodes were associated with episodes of ovarian oxytocin as demonstrated by Flint \& Sheldrick (1983) in ewes. During the early luteal phase in sheep, pulses of PGFM are infrequent but increase during the mid-luteal phase (Webb et al., 1981) which corresponds closely with the frequency of oxytocin pulses as observed here.

The secretion of prolactin is susceptible to a wide variety of external stimuli such as stress (Raud, Kiddy \& Odell, 1971), season (Schams \& Reinhardt, 1974) and the time of day (Koprowski, Tucker \& Convey, 1972). Some of these stimuli probably caused the large variation in prolactin secretion observed between cows in the present study. Nevertheless, pulses of prolactin were detected in some cows which were occasionally, but never consistently, associated with

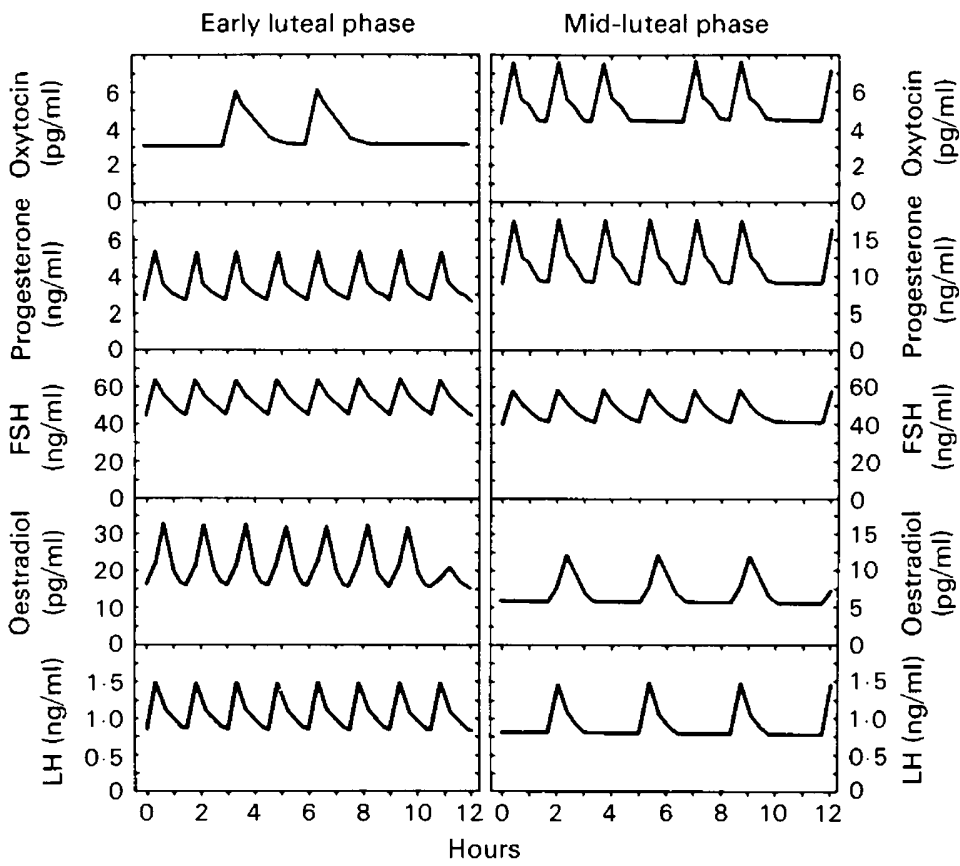

Text-fig. 7. Depiction of basal concentration, pulse amplitude and pulse frequency of LH, oestradiol, FSH, progesterone and oxytocin during the early and mid-luteal phases of the oestrous cycle. Calculations are based upon the means of the 7 cows studied. The shape of the idealized pulses is according to the average appearance of all compared pulses of the respective hormones. 
gonadotrophin pulses. In the present studies, even though prolactin concentrations varied considerably, all cows had oestrous cycles of normal length before, during and after the study. Therefore, as suggested by Hoffmann et al. (1974), the importance of peripheral concentrations of prolactin with regard to reproduction in the cow is questionable.

Based upon the present data and interrelationships, a schematic diagram of pulsatile secretion of gonadotrophins, ovarian steroids and ovarian oxytocin was composed (Text-fig. 7). It is suggested that pulses of LH and FSH stimulate pulses of oestradiol and progesterone from the ovary which in turn feed back upon the pituitary and hypothalamus to regulate the frequency and amplitude of the LH and FSH pulses. Also, pulsatile FSH secretion may be a better indirect indicator of pulsatile GnRH secretion than LH since FSH is inhibited much less than LH by the negative feedback action of steroids. Furthermore, it is suggested that pulses of ovarian oxytocin are involved with luteal function in the cyclic cow.

D.L.W. was a postdoctoral research fellow of the Alexander von Humboldt-Stiftung, Bonn, FRG. This work was supported by the Deutsche Forschungsgemeinschaft. We thank the NIAMDD for supplying us with NIH-FSH-B1 and NIH-P-B 3, and I. Redl and E. Gründl for expert technical assistance.

\section{References}

Adashi, E.Y., Jones, P.B.C. \& Hsueh, A.J.W. (1981) Synergistic effect of glucocorticoids on the stimulation of progesterone production by follicle-stimulating hormone in cultured rat granulosa cells. Endocrinology 109, 1888-1894.

Baird, D.T. \& McNeilly, A.S. (1981) Gonadotrophic control of follicular development and function during the oestrous cycle of the ewe. J. Reprod. Fert., Suppl. 30, 119-133.

Beck, T.W., Smith, V.G., Seguin, B.E. \& Convey, E.M. (1976) Bovine serum LH, GH and prolactin following chronic implantation of ovarian steroids and subsequent ovariectomy. J. Anim. Sci. 42, 461-468.

Convey, E.M. (1973) Neuroendocrine relationships in farm animals: a review. J. Anim. Sci. 37, 745-757.

Dorrington, J.H. \& Amstrong, D.T. (1979) Effects of FSH on gonadal functions. Recent Prog. Horm. Res. 35, 301-342.

Flint, A.P.F. \& Sheldrick, E.L. (1983) Evidence for a systemic role for ovarian oxytocin in luteal regression in sheep. J. Reprod. Fert. 67, 215-225.

Foster, J.P., Lamming, G.E. \& Peters, A.R. (1980) Shortterm relationships between plasma LH, FSH and progesterone concentrations in post-partum dairy cows and the effect of Gn-RH injection. J. Reprod. Fert. 59, 321-327.

Glencross, R.G., Munro, I.B., Senior, B.E. \& Pope, G.S. (1973) Concentrations of oestradiol-17 $\beta$, oestrone and progesterone in jugular venous plasma of cows during the oestrous cycle and in early pregnancy. Acta endocr., Copenh. 73, 374-384.

Goodman, R.L. \& Karsch, F.J. (1980) Pulsatile secretion of luteinizing hormone: Differential suppression by ovarian steroids. Endocrinology 107, 1286-1290.

Goodman, R.L., Pickover, S.M. \& Karsch, F.J. (1981) Ovarian feedback control of follicle-stimulating hormone in the ewe: evidence for selective suppression. Endocrinology 108, 772-777.
Henderson, K.M. \& Franchimont, P. (1981) Regulation of inhibin production by bovine ovarian cells in vitro. $J$. Reprod. Fert. 63, 431-442.

Hixon, J.E., Pijanowski, G.J., Weston, P.G., Shanks, R.D. \& Wagner, W.C. (1983) Evidence for oscillator other than luteinizing hormone controlling the secretion of progesterone in cattle. Biol. Reprod. 29 , 1155-1162.

Hoffmann, B., Kyrein, H.J. \& Ender, M.L. (1973) An efficient procedure for the determination of progesterone by radioimmunoassay applied to bovine peripheral plasma. Hormone Res. 4, 302-310.

Hoffmann, B., Schams, D., Bopp, R., Ender, M.L., Giménez, T. \& Karg, H. (1974) Luteotrophic factors in the cow: evidence for LH rather than prolactin. $J$. Reprod. Fert. 40, 77-85.

Ireland, J.J. \& Roche, J.F. (1982) Effect of progesterone on basal LH and episodic LH and FSH secretion in heifers. J. Reprod. Fert. 64, 295-302.

Kesner, J.S. \& Convey, E.M. (1982) Interaction of estradiol and luteinizing hormone releasing hormone on follicle stimulating hormone release in cattle. $J$. Anim. Sci. 54, 817-821.

Kesner, J.S., Padmanabhan, V. \& Convey, E.M. (1982) Estradiol induces and progesterone inhibits the preovulatory surges of luteinizing hormone and folliclestimulating hormone in heifers. Biol. Reprod. 26, 571578.

Koprowski, J.A., Tucker, H.A. \& Convey, E.M. (1972) Prolactin and growth hormone circadian periodicity in lactating cows. Proc. Soc. exp. Biol. Med. 140, 1012-1014.

Korenman, S.G., Stevens, R.H., Carpenter, L.A., Robb, M., Niswender, G.D. \& Sherman, B.M. (1974) Estradiol radioimmunoassay without chromatography: procedure, validation and normal values. $J$. clin. Endocr. Metab. 38, 718-720.

Levine, J.E., Pau, K.-Y.F., Ramirez, V.D. \& Jackson, 
G.L. (1982) Simultaneous measurement of luteinizing hormone-releasing hormone and luteinizing hormone release in unanesthetized, ovariectomized sheep. Endocrinology 111, 1449-1455.

Mann, J.G. \& Niswender, G.D. (1983) FSH receptors in the bovine corpus luteum. J. Anim. Sci. 57, Suppl. 1, 354, Abstr. 536.

McNeilly, A.S., O'Connell, M. \& Baird, D.T. (1982) Induction of ovulation and normal luteal function by pulsed injections of luteinizing hormone in anestrous ewes. Endocrinology 110, 1292-1299.

Padmanabhan, V. \& Convey, E.M. (1981) Progesterone inhibits the ability of estradiol to increase basal and luteinizing hormone-releasing hormone-induced luteinizing hormone release from bovine pituitary cells in culture: neither progesterone nor estradiol affects follicle-stimulating hormone release. Endocrinology 109, 1091-1096.

Rahe, C.H., Owens, R.E., Fleeger, J.L., Newton, H.J. \& Harms, P.G. (1980) Pattern of plasma luteinizing hormone in the cyclic cow: dependence upon the period of the cycle. Endocrinology 107, 498-503.

Raud. H.R., Kiddy, C.A. \& Odell, W.D. (1971) The effect of stress upon the determination of serum prolactin by radioimmunoassay. Proc. Soc. exp. Biol. Med. 136, 689-693.

Roche, J.F. \& Ireland, J.J. (1981) The differential effect of progesterone on concentrations of luteinizing hormone and follicle-stimulating hormone in heifers. Endocrinology 108, 568-572.

Romanoff, E.B. (1966) Steroidogenesis in the perfused bovine ovary. J. Reprod. Fert., Suppl. 1, 89-99.

Schallenberger, E. \& Peterson, A.J. (1982) Effect of ovariectomy on tonic gonadotrophin secretion in cyclic and post-partum dairy cows. J. Reprod. Fert. 64, 47-52.

Schallenberger, E., Rampp, J. \& Walters, D.L. (1983) Pulsatile progesterone secretion occurs during midgestation in the cow even though pulsatile $\mathbf{L H}$ secretion is abolished. J. Anim. Sci. 57, Suppl. 1, 371, Abstr. 577.

Schallenberger, E., Schams, D., Bullermann, B. \& Walters, D.L. (1984) Pulsatile secretion of gonadotrophins, ovarian steroids and ovarian oxytocin during prostaglandin-induced regression of the corpus luteum in the cow. $J$. Reprod. Fert. 71, 493-501.

Schams, D. (1983) Oxytocin determination by radioimmunoassay. III. Improvement to subpicogram sensitivity and application to blood levels in cyclic cattle. Acta endocr., Copenh. 103, 180-183.

Schams, D. \& Karg, H. (1969a) Radioimmunologische LH-Bestimmung im Blutserum vom Rind unter besonderer Berücksichtigung des Brunstzyklus. Acta endocr., Copenh. 61, 96-103.

Schams, D. \& Karg, H. (1969b) Radioimmunologische Bestimmung von Prolaktin im Blutserum vom Rind. Milchwissenschaft 24, 263-265.

Schams, D. \& Reinhardt, V. (1974) Influence of the season on plasma prolactin level in cattle from birth to maturity. Hormone Res. 5, 217-226.
Schams, D. \& Schallenberger, E. (1976) Heterologous radioimmunoassay for bovine follicle-stimulating hormone and its application during the oestrous cycle in cattle. Acta endocr., Copenh. 81, 461-473.

Schams, D., Grombe, S., Schallenberger, E., Reinhardt, V. \& Claus, R. (1978) Relationship between short-term variations of $\mathrm{LH}, \mathrm{FSH}$, prolactin and testosterone in peripheral plasma of prepubertal bulls. $J$. Reprod. Fert. 54, 145-148.

Schams, D., Lahlou-Kassi, A. \& Glatzel, P. (1982) Oxytocin concentrations in peripheral blood during the oestrous cycle and after ovariectomy in two breeds of sheep with low and high fecundity. $J$. Endocr. 92, 9-13.

Sears, P.M., Paape, M.J., Pearson, R.E. \& Gwazdauskas, F.C. (1978) Comparison between tail vein and jugular vein cannulation in cattle. J. Dairy Sci. 61, 974-979.

Sheldrick, E.L. \& Flint, A.P.F. (1981) Circulating concentrations of oxytocin during the estrous cycle and early pregnancy in sheep. Prostaglandins 22, 631636.

Short, R.E., Randel, R.D., Staigmiller, R.B. \& Bellows, R.A. (1979) Factors affecting estrogen-induced LH release in the cow. Biol. Reprod. 21, 683-689.

Thanki, K.H. \& Channing, C.P. (1978) Effect of FSH and estradiol upon progesterone secretion by porcine granulosa cells in tissue culture. Endocrinology 103, 74-80.

Walters, D.L. \& Schallenberger, E. (1983) Kurzzeitsekretion von Östradiol-17ß und Progesteron beim RindVergleich der Konzentrationen im Blutplasma der V. cava und V. jugularis. Wien. tierärztl. Mschr. 70, 247248.

Walters, D.L. \& Schallenberger, E. (1984) Pulsatile secretion of gonadotrophins, ovarian steroids and ovarian oxytocin during the periovulatory phase of the oestrous cycle in the cow. J. Reprod. Fert. 71, 503512.

Walters, D.L., Short, R.E., Convey, E.M., Staigmiller, R.B., Dunn, T.G. \& Kaltenbach, C.C. (1982) Pituitary and ovarian function in postpartum beef cows. III. Induction of estrus, ovulation and luteal function with intermittent small-dose injections of $\mathrm{GnRH}$. Biol. Reprod. 26, 655-662.

Wathes, D.C. \& Swann, R.W. (1982) Is oxytocin an ovarian hormone? Nature, Lond. 297, 225-227.

Webb, R., Mitchell, M.D., Falconer, J. \& Robinson, J.S. (1981) Temporal relationships between peripheral concentrations of oxytocin, progesterone and 13,14dihydro-15-keto-prostaglandin $\mathrm{F}_{2 \alpha}$ during the estrous cycle and early pregnancy in the ewe. Prostaglandins 22, 443-453.

Wettemann, R.P., Hafs, H.D., Edgerton, L.A. \& Swanson, L.V. (1972) Estradiol and progesterone in blood serum during the bovine estrous cycle. J. Anim. Sci. 34, 1020-1024.

Received 25 October 1983 